\title{
LXI. Decomposition of glass by carbon dioxide held in solution in capillary films of water
}

\section{Prof. R. Bunsen}

To cite this article: Prof. R. Bunsen (1886) LXI. Decomposition of glass by carbon dioxide held in solution in capillary films of water , Philosophical Magazine Series 5, 22:139, 530-532, DOI: $10.1080 / 14786448608627968$

To link to this article: http://dx.doi.org/10.1080/14786448608627968

册 Published online: 29 Apr 2009.

Submit your article to this journal $[\pi$

Џll Article views: 2

Q View related articles $\widetilde{ }$ 
doubling ought to be at any particular distance from a single ridge is now easily calculated from the second line of equation (48), and will be actually calculated for the case of these curves, and probably also for some other cases for numerical illustrations, which I hope to give in Part IV.

LXI. Decomposition of Glass by Carbon Dioxide held in Solution in Capillary Films of Water. By Prof. R. Bunsen**

$\mathrm{T}$ an earlier publication $\dagger \mathrm{I}$ have given my investigations of the phenomena which present themselves when carbon dioxide is allowed to act on capillary glass threads covered with an extremely thin film of moisture. According to these investigations, it appears that $49 \cdot 453$ grammes of such capillary threads are able in 109 days to take up so much carbon dioxide, that on heating not less than $236^{\circ} 9$ cubic centim. of this gas is set free. The gas so retained in the water-film, showed towards pressure and temperature precisely the relations which are presented in the ordinary phenomena of gas absorption by liquids. In these experiments, as in all that have been previously carried out, it has been assumed, both from the result of direct observation and on theoretical grounds, that the action of carbon dioxide on glass may be entirely disregarded. And, indeed, experiments were carried out in my laboratory seventeen years ago by Dr. Emmerling, which showed that glass vessels in which an 11 per cent. solution of hydrochloric acid was boiled for hours together did not lose $0.0005 \mathrm{grm}$. in weight. If, in addition to this, we bear in mind that under ordinary atmospheric pressure, at $15^{\circ} \mathrm{C}$., water dissolves only $0 \cdot 2$ per cent. by weight of carbon dioxide, an acid which is set free from all its compounds even by the weakest acids, and, further, that repeated observations show that dry carbon dioxide has practically no action upon dry glass, then it must appear almost absurd to attempt to explain the gradual fixation of carbon dioxide on glass dried by calcium chloride by a chemical decomposition of the glass.

But the matter presents itself under quite a different aspect when we have regard to the phenomena of absorption as occurring in capillary films. Water which at $15^{\circ} \mathrm{C}$. and

* Translated from Wied. Ann. x. pp. 161-165 (1886), by G. H. Bailey, D.Sc., Ph.D.

† Wied. Ann. xxiv. p. 321 (1885). 
0.76 metre pressure takes up about 0.2 per cent. of its weight of carbon dioxide behaves quite differently in capillary films, for it is not then under a pressure of one atmosphere, but under a very high capillary pressure, and so can take up so much more carbon dioxide, that, if we would study the decomposing action of the solution, we have no ground of comparison, and must solve the problem by direct experiment.

Such an experiment could not be carried out either before or during the previous experiments without destroying the capillary glass thread; and thus it was not possible to proceed with the examination of this question till the experiments already proceeding were finished.

The 49.453 grms. of glass used were, for this purpose, removed from the measuring tube and extracted with cold distilled water of such a purity that it left only $\frac{1}{500,000}$ solid residue on evaporation. For the extraction, portions of 300 grammes of water were taken, and the whole 3000 grammes so used were filtered throngh a double filter and evaporated to dryness in a platinum vessel. The residue dissolved in hydrochloric acid with evolution of carbon dioxide, and contained 0.8645 grm. of sodium chloride and $0.0608 \mathrm{grm}$. of silica along with unweighable traces of calcium chloride or potassium chloride.

From the composition of the capillary threads *, it appears therefore that there was not less than $2.882 \mathrm{grms}$. of the glass decomposed, or 5.83 per cent. of the whole quantity used. We see, then, that the chemical action of carbon dioxide under the influence of pressure in capillary films is far greater than we had any cause to expect. 'The carbon dioxide had, in the course of the experiments, taken up from the glass a quantity of soda corresponding to $0.7841 \mathrm{grm}$. sodium carbonate, and containing $0.325 \mathrm{grm}$. carbon dioxide.

Since sodium carbonate is not decomposed, even at very high temperatures, the 236.9 cubic centim. or $0.4659 \mathrm{grm}$. of carbon dioxide set free on heating could not arise from this decomposition product of the glass thread. But sodium carbonate takes up carbon dioxide and is transformed into the bicarbonate, and this carbon dioxide is set free again on heating, exactly in the same manner as in these observations.

It is thus to be determined whether the phenomena observed in capillary absorption can be exclusively attributed to the formation of sodium carbonate.

If we start from the most unfavourable supposition that all the sodium carbonate formed became bicarbonate, and that

*Wied. Ann. xx. p. 545 (1883) [Phil. Mag. March 1884]. 
the temperature to which the glass was heated was sufficiently high to expel the whole of the carbon dioxide, then we can only account for 165.2 cubic centim. of carbon dioxide instead of 236.9 cubic centim. There must therefore, even under the most unfavourable conditions, have been at least 71.7 cubic centim. of carbon dioxide fixed on the glass otherwise than by chemical union. We cannot unfortunately determine how much, however, actually was due to the decomposition of the glass and how much to the capillary absorption. If, then, carbon dioxide, under the conditions described, can overcome the affinity of silica for soda, a similar action, although in a lesser degree, may bo expected from pure water.

That such an action really does take place may be expected, if one may draw a conclusion from the action at higher temperatures, as indicated by the following fact, which I had occasion to observe in the preliminary experiments on the estimation of the tension of water-vapour at very high temperatures. In these experiments I made use of narrow thick-walled tubes, sealed at the upper end, and attached at the lower end to a calibrated capillary tube 2 metres long, and which would withstand a pressure of 600 to 800 atmospheres. In the wider part of the tube containing air there was, standing over the mercury column by which the approximate pressure was measured, a column of water, and this was heated to $550^{\circ} \mathrm{C}$. in the thermostat described *.

At the part of the wall of the tube with which the water had been in contact there were alterations of a marked character.

The glass was transformed to more than a third of its thickness into a hard white porcelain-like mass, and the inner cavity of the tube diminished to one-tenth of its original diameter. There can be no doubt therefore that glass and other silicates intended to be used in the examination of such questions are quite inapplicable.

In order to obtain trustworthy results in absolute measure without the interference of chemical influence, there remains scarcely any other course than to repeat the whole of the experiments on capillary absorption with very fine gold or platinum wire, and allow for the chemical action on the relatively small surface of the glass measuring-tube. 